\title{
Correction: The dynamics of vertebrate homeobox gene evolution: gain and loss of genes in mouse and human lineages
}

Ying-fu Zhong and Peter WH Holland ${ }^{*}$

\section{Correction}

After publication of this work [1], we found evidence for a gene (or two tandem genes) orthologous to Leutx in a genome assembly for the African elephant produced by the Broad Institute and accessible on the UCSC Genome Browser, assembly version Broad/loxAfr3 [2]. Elephant Leutx homeodomain sequences are highly divergent from that of human LEUTX (48\% identity), but regions of identity outside the homeodomain plus genomic synteny (Figure 1) confirm orthology. We also found divergent putative Leutx orthologues in some other mammals including dog, cat, horse, pig and cow but, as reported in our original publication, not in rodents or outside the placental mammals. These find-

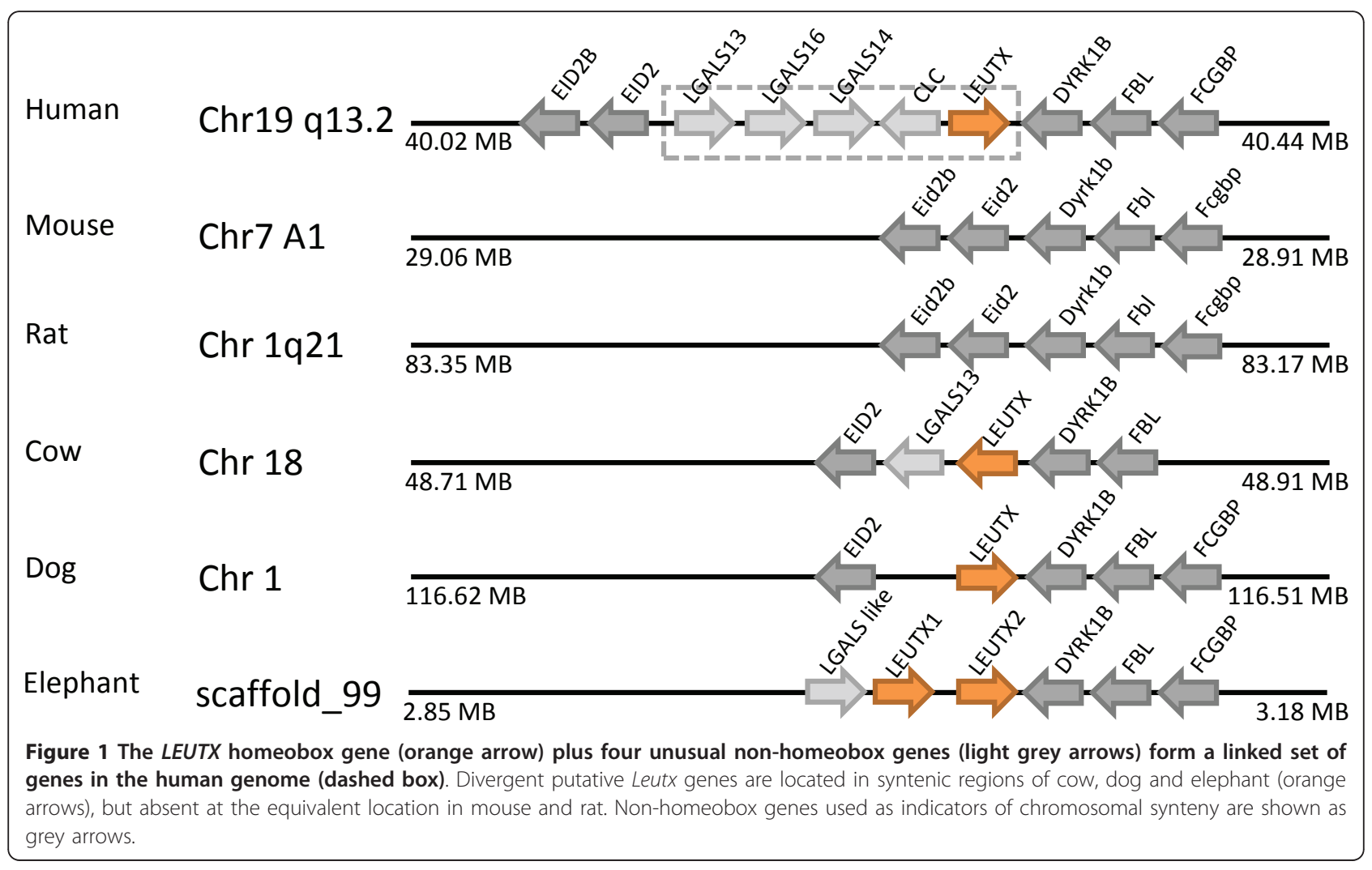

* Correspondence: peter.holland@zoo.ox.ac.uk

Department of Zoology, University of Oxford, South Parks Road, Oxford, OX1

3PS, UK

\section{Biomed Central}

(c) 2011 Zhong and Holland; licensee BioMed Central Ltd. This is an Open Access article distributed under the terms of the Creative Commons Attribution License (http://creativecommons.org/licenses/by/2.0), which permits unrestricted use, distribution, and reproduction in any medium, provided the original work is properly cited. 


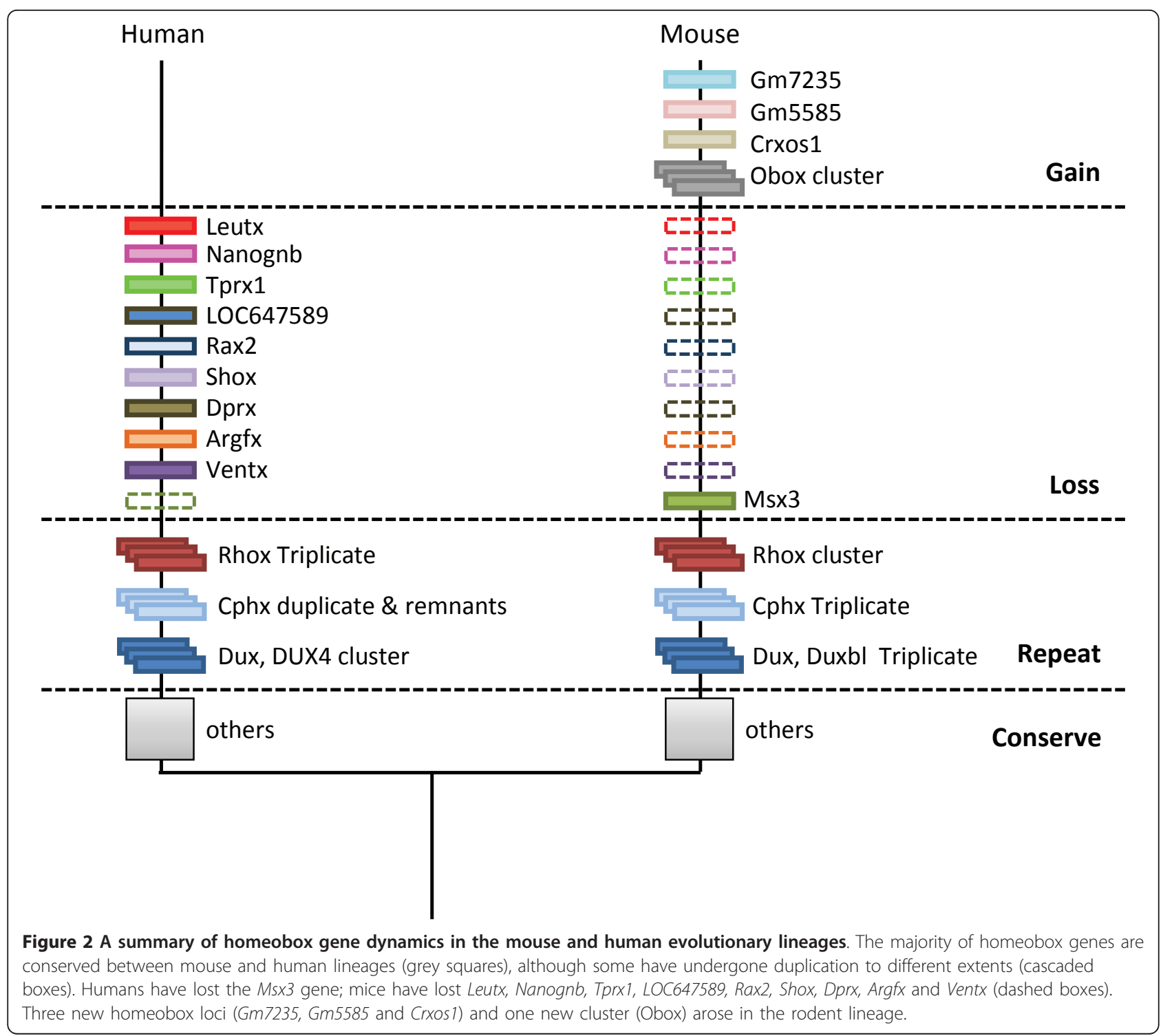

ings imply that Leutx did not originate in primate evolution as we originally suggested [1], but arose early in the radiation of placental mammals and was secondarily lost from rodents. This finding strengthens our original conclusion that rodents have experienced far more homeobox gene loss than have primates. Leutx is added to Ventx, Argfx, Dprx, Shox, Rax2, LOC647589, Tprx1 and Nanognb on the list of homeobox genes lost in the evolutionary lineage leading to rodents (Figure 2).

Received: 8 July 2011 Accepted: 13 July 2011 Published: 13 July 2011

\section{References}

1. Zhong Y-F, Holland PWH: The dynamics of vertebrate homeobox gene evolution: gain and loss of genes in mouse and human lineages. BMC Evolutionary Biology 2011, 11:169.

2. UCSC Genome Browser. [http://UCSC Genome Browser Home] doi:10.1186/1471-2148-11-204

Cite this article as: Zhong and Holland: Correction: The dynamics of vertebrate homeobox gene evolution: gain and loss of genes in mouse and human lineages. BMC Evolutionary Biology 2011 11:204.

\section{Submit your next manuscript to BioMed Central} and take full advantage of:

- Convenient online submission

- Thorough peer review

- No space constraints or color figure charges

- Immediate publication on acceptance

- Inclusion in PubMed, CAS, Scopus and Google Scholar

- Research which is freely available for redistribution 